\title{
THE TRADEOFF BETWEEN EX ANTE AND EX POST TRANSACTION COSTS: EVIDENCE FROM LEGAL OPINIONS
}

\author{
Benito Arruñada and Carlos A. Manzanares*
}

\begin{abstract}
Business firms' formalization has been seen primarily as an entry barrier, which has often led to policies focused on simplifying formalities and creating minimalist company registries. This approach has been criticized on theoretical grounds for ignoring the tradeoff between ex ante registration and ex post transaction costs. This paper tests for the presence of this tradeoff in the context of company registries. In particular, using purpose-built indexes, we test for whether stronger registration requirements decrease the length of lawyer comments on model transactional legal opinions included in an authoritative report on legal opinions created by the International Bar Association. These lawyer comments proxy for due-diligence costs associated with executing large, cross-country company transactions. We confirm the presence of the tradeoff by finding that in countries with less stringent registration requirements, legal opinion comments are longer, even after controlling for the legal origin, European Union affiliation, and the log of per capita GDP.
\end{abstract}

Keywords: business registries, company law, business formalization, impersonal transactions, information asymmetry, transaction costs, Doing Business.

JEL Classification: O17, K22, K23, L59.

\footnotetext{
* Benito Arruñada, Professor of Business Organization, Department of Economics and Business, Pompeu Fabra University and Barcelona Graduate School of Economics. Carlos A. Manzanares, PhD Candidate, Department of Economics, Vanderbilt University. This work has benefitted from exchanges with Henry Hansmann, José Massaguer, Áurea Suñol, Giorgio Zanarone, Maristella Botticini, Mikhail Drugov, Yesha Yadav, participants at the International Society for New Institutional Economics Conference at Stanford University, the European School on New Institutional Economics in Corsica, France, and the Mercatus Center Adam Smith Fellowship Summer Colloquium at George Mason University. We also gratefully acknowledge the detailed explanations of legal opinion practice given to us by A. Bindu Liang at Waller, Lansden, Dortch \& Davis, LLP, as well as the excellent research assistance provided by Ian Todd. The usual disclaimers apply. We received financial support from the European Commission, through project CIT3-513420; the Spanish Ministry of Economy and Competitiveness, through Project ECO201457131R; the Spanish Commission of Cultural, Educational, and Scientific Exchange Programs and the U.S. Department of State, Bureau of Educational and Cultural Affairs (Fulbright Program).
} 


\section{CONTENTS}

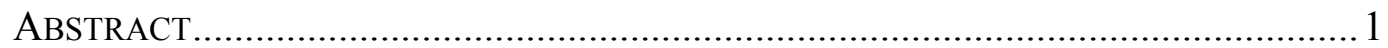

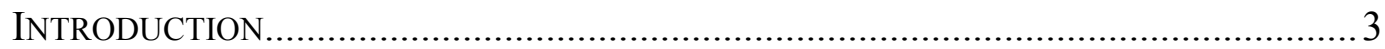

I. THEORY AND TESTABLE PREDICTION ............................................................. 7

A. A Theory of Business Registries ........................................................ 7

B. Due Diligence and Legal Opinions ..................................................... 10

C. Testable Prediction .............................................................................. 12

II. Qualitative Analysis of Two EXTREME CASES: Business REGISTRIES IN THE UNITED STATES AND GERMANY ....................................... 14

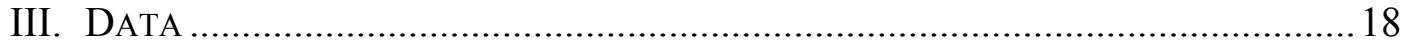

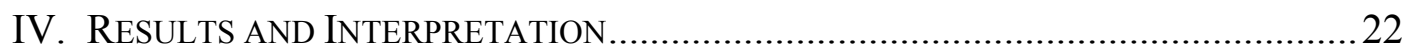

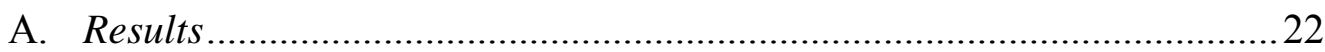

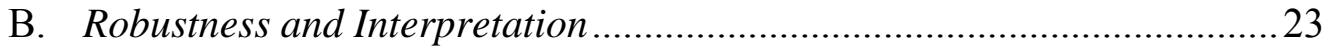

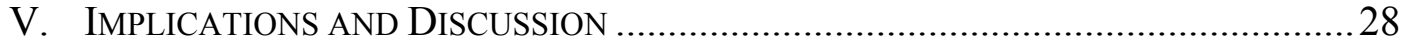

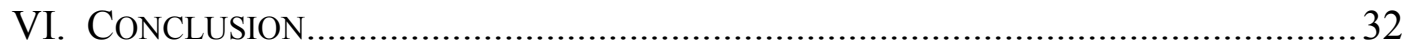

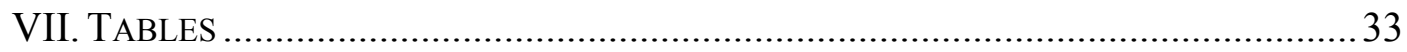

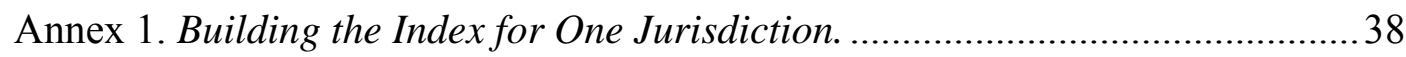

Annex 2. Entities and Governing Documents Studied........................................39 


\section{INTRODUCTION}

Policy discussions concerning the organization of business formalities have become more prevalent in recent decades. These discussions, reminiscent of widespread arguments in developed economies of the nineteenth century, have led to a series of policy initiatives, such as the World Bank's Doing Business reports, which have devoted extensive resources to simplifying registration requirements for business firms, seeing these requirements primarily as entry barriers. However, as argued by Arruñada (2007), the fundamental approach of these initiatives tends to disregard the role of business registries as providers of information for judges, government departments, and, mainly, other firms. ${ }^{1}$ Further, it ignores potential tradeoffs between business registration and transaction costs associated with future contracts. The trivialization of this information serving, contract-facilitating role has not been limited to policy. It has its roots in those theories of the firm dominated by a contractual emphasis, which traditionally see the role of the State as limited to providing a set of default rules for contracts, a judiciary that enforces contracts, and mechanisms to mitigate externalities. ${ }^{2}$ Within this theoretical framework, there is little need for business registration.

Arruñada (2010) proposes a property theory of business registries and argues that, by making some contracts public and verifiable, registries facilitate later company contracting while preserving consent of company owners to a diminishment of their property rights. ${ }^{3}$ The theory can be

\footnotetext{
${ }^{1}$ Benito Arrunada, Pitfalls to Avoid when Measuring the Institutional Environment: Is 'Doing Business' Damaging Business?, 35 J. CoMP. ECON. 729 (2007).

${ }^{2}$ See generally, Ronald H. Coase, The Nature of the Firm, 4 ECONOMICA 386 (1937); Armen A. Alchian \& Harold Demsetz, Production, Information Costs, and Economic Organization, 62 AM. ECON. Rev. 777 (1972); Michael C. Jensen \& William H. Meckling, Theory of the Firm: Managerial Behavior, Agency Costs and Ownership Structure, 3 J. Fin. ECON. 305 (1976); OLIVER E. WILLIAMSON, MARKETS AND HIERARCHIES: ANALYSIS AND ANTITRUST IMPLiCATIONS (1975); OlIVER E. Williamson, THE ECONOMIC institutions of CApitalism: Firms, Markets, Relational Contracting (1985); Benjamin Klein, Robert G. Crawford, \& Armen A. Alchian, Vertical Integration, Appropriable Rents, and the Competitive Contracting Process, 21 J.L. \& ECON. 297 (1978); Sanford J. Grossman \& Oliver D. Hart, The Costs and Benefits of Ownership: A Theory of Vertical and Lateral Integration, 94 J. POL. ECON. 691 (1986); Bengt Holmstrom \& Paul Milgrom, The Firm as an Incentive System, 84 AM. ECON. REV. 972 (1994).

${ }^{3}$ Benito Arruñada, Institutional Support of the Firm: A Theory of Business Registries, 2 J. LEGAL ANALYSIS 525 (2010).
} 
summarized as follows. Although property rights provide incentives for investment and specialization (between principals and agents), strict enforcement (for real property, in rem enforcement) creates transaction costs in the form of worsened information asymmetry between property owners and acquirers. In the company context, transactions can be seen as the product of "sequential" exchange, which involves at least two steps. First, company principals (owners) enter into "originative" transactions (mainly, charters, bylaws, company resolutions, and agent appointments) with themselves and with company agents (mainly, directors and officers). Originative transactions establish vital characteristics of the firm, including the decision-making structure and procedures necessary for the company to bind itself to contracts with outside parties, as well as the company's ownership structure. Originative transactions involve a reallocation of property rights (and power to transfer these rights) among principals and agents, and in principle, these transactions must be respected to legally commit the company to "subsequent" transactions between the company and outside (third) parties. Therefore, third parties entering into subsequent transactions with a company face substantial transaction costs caused by information asymmetry: namely, they need to verify the contents of the company's originative transactions to make sure that the company is legally bound to the subsequent transaction. Otherwise, if things turn out badly, third parties may end up with indemnity claims against individual company agents, rather than with a more valuable legal claim against the company itself. Therefore, in this scenario, there is a potential conflict between the parties to originative transactions (i.e. principals and their agents), and third parties who wish to contract with the company. In the event of a legal dispute, this conflict can be resolved in favor of the principal, by strictly enforcing originative transactions, or in favor of the third party, by weakly enforcing originative transactions. On the one hand, strict enforcement of originative transactions strengthens property rights of company owners but also increases transaction costs for third parties, inhibiting impersonal trade. On the other hand, weak enforcement of originative transactions lowers transaction costs for third parties but also diminishes the property rights of company owners, inhibiting investment and specialization.

Along these lines, business registries serve to publicize the contents of a company's originative transactions in a verifiable manner, lowering transaction costs for third parties entering into subsequent transactions with the firm while giving company owners control over the content of the originative transactions they register, preserving their consent. Although all business registries perform this fundamental publicity role to some degree, different jurisdictions vary in the extent to which originative transactions are publicly registered, setting up an empirical opportunity. A testable 
prediction of the theory is that weaker (stronger) ex ante registration requirements should result in higher (lower) costs of subsequent contracting, ex post to registration.

This article tests for the presence of this tradeoff between the extent of ex ante company registration and the extent of legal due diligence reviews used to support transactional legal services, ex post to registration. We focus on "legal opinions" which are requested by one contracting party from the legal counsel of the other contracting party (usually, the company) prior to the consummation of large company contracts. In our tests, we exploit differential registration requirements across countries as well as a crosssection of model transactional legal ("closing") opinion comments collected by the International Bar Association. ${ }^{4}$ These comments were created by lawyers and they discuss the application of a model legal opinion to each particular country and detail the customary legal due diligence review necessary in each country.

These legal opinions contain a discussion of various legal issues pertaining to the contract, and, in order to render them, legal counsels must undergo an extensive documentary investigation of the originative transactions of the company as part of the due diligence review process supporting the opinion. The extent of this due diligence review is a major driver of legal opinion costs, which in turn makes up a significant portion of transaction costs experienced by parties entering into large company contracts. For example, the Opinions Committee of the California State Bar Business Law Section discusses the risk that California case law would impose additional due diligence requirements on lawyers "with attendant time and monetary costs." ${ }^{5}$ Similarly, the TriBar Opinion Committee advises lawyers to communicate with their clients any attempt to undertake more than the usual amount of due diligence, emphasizing that: "the cost of any additional diligence may be a significant factor to be considered by the parties to the transaction."

The dataset we use does not provide direct information on legal opinion costs. Instead, we use the lengths of legal opinion comments, which describe the due diligence review involved in rendering legal opinions in a given country, as proxies for the average cost of issuing legal opinions

\footnotetext{
${ }^{4}$ Michael Gruson \& Stephan HUtTer, InT'L Bar Ass'N, ACQUisition OF SHARES in a Foreign Country: Substantive LaW and Legal Opinions (1993); Michael

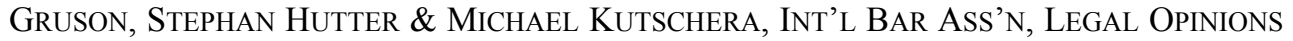
IN INTERNATIONAL TRANSACTIONS (4th ed. 2003).

${ }^{5}$ Opinions Committee of the California State Bar Business Law Section, Toward a National Legal Opinion Practice: The California Remedies Opinion Report, 60 Bus. LAW. 907, 929 (2005).

${ }^{6}$ TriBar Opinion Committee, Third Party 'Closing' Opinions, 53 Bus. Law. 591, 610 (1998).
} 
attributable to the due diligence review process, by country. Using this data, we compare company registration requirements in each country with the length of legal opinion comments to determine whether weaker registration requirements are associated with longer legal opinion comments.

Our results indicate that even controlling for legal origin, E.U. affiliation, and the log of per capita GDP, countries with weaker registration requirements also have longer legal opinion comments. This finding provides novel empirical support for the presence of this tradeoff in the context of business registries, complementing analogous results in the context of property registries. ${ }^{7}$ The existence of tradeoffs between ex ante registration and transaction costs ex post to registration advises cautious application of policy prescriptions that seek to simplify registration requirements and rank countries based only on the extent of ex ante public registration procedures and costs. ${ }^{8}$ Instead, our results motivate more comprehensive studies of the efficiency of registration institutions that fully account for both ex ante registration and ex post transaction costs. Additionally, our results contribute to a growing literature studying "legal" information asymmetries, i.e. those induced by the superior information of one party concerning the quality of legal title transferred, which complements an extensive literature on "substantive" information asymmetries, i.e. those induced by the superior information of one party concerning the quality of the underlying good or service. ${ }^{9}$ Further, our

\footnotetext{
${ }^{7}$ For example, using survey data compiled by the European Mortgage Federation, BENITO ARRuÑAdA, InSTITUTIONAL FoundATIONS OF IMPERSONAL EXCHANGE: THEORY AND Policy of Contractual Registries 156-160 (2012) found that more extensive registration of real property was associated with smaller mortgage provision costs and repossession times. In a similar vein, $i d$. at 74-75, 114 documents the challenges, ex post to registration, caused by the streamlined registration procedures of the Mortgage Electronic Registration System (MERS) in the secondary mortgage context of the U.S. as well as of the U.S. Patent and Trademark Office in the patent context, id. at 222-223.

${ }^{8}$ See, e.g., Hernando De Soto, The Other Path: The Invisible Revolution in THE THIRD WORLD (1989); Simeon Djankov, Rafael La Porta, Florencio Lopez-de-Silanes, and Andrei Shleifer, The Regulation of Entry, 117 Q. J. ECON. 1 (2002); World Bank, Doing Business (2003-2015), available at http://www.doingbusiness.org/.

9 "Legal" information asymmetries have been studied by Benito Arruñada, Property Enforcement as Organized Consent, 19 J.L. ECON. \& ORG. 401 (2003); and Benito Arruñada \& Nuno Garoupa, The Choice of Titling System in Land, 48 J.L. \& ECON. 709 (2005) (in the context of property registries, where the property seller possesses superior knowledge of the quality of land title); Arruñada (2010), supra note 3 (in the context of business registries, the sale of movable property, and agency relationships, where one party possesses superior knowledge of the contents of originative transactions); and Jonathan $\mathrm{M}$. Barnett, Certification Drag: The Opinion Puzzle and Other Transactional Curiosities, 33 J. CORP. L. 95 (2007) (who studies whether legal opinions are cost-justified and proposes alternative explanations for the emergence of legal opinion practice). Substantive information asymmetries include, for example, those induced by superior information by
} 
results provide empirical evidence of a tradeoff between public and private certification intermediaries (registration and legal opinions, respectively), ${ }^{10}$ as well as between "mandatory" and "voluntary" disclosure requirements in the analogous context of product quality. ${ }^{11}$

The paper is organized as follows. Part I presents a theory of business registries, introduces the due diligence review process and legal opinions, and advances a testable prediction of the theory. Part II presents a qualitative analysis of the expected tradeoff between ex ante registration procedures and due diligence reviews, ex post to registration, relying on the extreme cases of the United States and Germany. Part III introduces the dataset. Part IV presents and discusses the quantitative tests and their findings. Part V examines some of the article's implications. Part VI concludes.

\section{TheORY AND TeStABle PREDICTION}

\section{A. A Theory of Business Registries}

Company contracting is sequential, which involves at least two steps. First principals, who include owners and shareholders, voluntarily contract with themselves and with agents, such as employees, company directors and managers, in "originative" transactions (charters, bylaws, board and shareholder resolutions, agent appointments). Second, agents enter into "subsequent" transactions with third parties, such as company clients, company creditors and future shareholders, on behalf of the company. ${ }^{12}$

Although this sequential exchange allows for specialization in the contractual tasks of principals and agents, it gives rise to a particular type of transaction costs because third parties dealing with the principal's agent suffer from information asymmetry with respect to the previous originative

one party on the quality of an underlying product, see, e.g., Andrew F. Daughety \& Jennifer F. Reinganum, Communicating Quality: A Unified Model of Disclosure and Signaling, 39 RAND J. ECON. 973 (2008).

${ }^{10}$ The literature on certification intermediaries is extensive. For a good review, see David Dranove \& Ginger Zhe Jin, Quality Disclosure and Certification: Theory and Practice, 48 J. ECON. LIT. 935 (2010).

${ }^{11}$ See, e.g., Daughety \& Reinganum, supra note 9.

${ }^{12}$ Arruñada (2010), supra note 3. 
transaction. In addition, after the third party has entered into the subsequent transaction, the principal's incentives may change, creating a moral hazard problem on the part of the principal. Before the subsequent transaction is agreed upon, principals have an interest in convincing third parties that the originative transactions have been complied-with; however, if the outcome of the subsequent transaction turns out badly, principals have an incentive to assert a defect in the originative transaction, thereby invalidating the subsequent transaction.

To make this discussion more concrete, consider a lender (the third party) that would like to extend a loan to a company borrower. The company borrower consists of principals (company owners) and agents (company directors, officers, and employees) who have entered into a set of originative transactions, namely the corporate charter and bylaws. These originative transactions establish the procedures by which the company's agents can bind the company to a contract. For example, the company charter and bylaws may establish that the company can be bound to a loan contract only if a majority of the directors of the company approves a resolution authorizing the loan at a meeting where a pre-specified quorum of directors is present. In our analysis, this resolution is also an originative transaction. Also, the company bylaws may establish that only a director in good standing may sign the contract on behalf of the company. When contracting with the lender, a company director presents a certified copy of the authorizing resolution and a copy of the company's charter and bylaws, and asserts that he is authorized to sign on behalf of the company. Absent an institutional solution, the lender suffers from information asymmetry concerning the authenticity of the documents presented as well as the authority of the director to act on behalf of the company. Further, to secure the loan, the owners have an incentive to convince the lender that all necessary requirements to bind the firm to the contract have been met. However, if the company later struggles to pay the loan, the owners have an incentive to argue that the company authority-delegation requirements were never satisfied.

Sequential transactions lend themselves to this type of dispute: a principal may have an incentive to elude obligations entered into on his behalf by an agent whether or not the agent had the legal authority to bind the principal. The law can adjudicate these types of disputes in favor of the principal or the third party. On the one hand, a legal rule can demand strict compliance with originative transactions, and, absent this strict compliance, declare the subsequent transaction invalid, favoring the principal (strict enforcement of the originative transaction). In the previous example, this would involve allowing the owners to escape the terms of the loan contract if the execution of the contract had not complied with all company 
authority-delegation procedures. This type of legal rule (one that favors the principal) maximizes property enforcement and incentives for investment by principals as well as specialization in the tasks of principals and agents but will worsen the information asymmetry suffered by potential third parties with respect to originative transactions. On the other hand, a legal rule can allow the subsequent transaction to remain valid notwithstanding defects in compliance with the originative transactions, favoring the third party (weak enforcement of the originative transaction). In the lending example, this would allow the loan to remain valid even if the company borrower did not comply with its internal authority-delegation procedures. This type of legal rule (one that favors the third party) will minimize information asymmetry for potential third parties, encouraging them to trade, but will also weaken property enforcement. Therefore, the choice of legal rule involves a tradeoff between property enforcement and transaction costs.

Legal systems have attempted to overcome this tradeoff by a combination of formal business registration and informal solutions based on appearance, such as the doctrine of apparent authority in the United States. ${ }^{13}$ Registration of originative transactions - the charters, bylaws, and any amendments to them (including relevant board or shareholder resolutions and agent appointments) - manages this tradeoff by giving principals control over the contents of the originative transactions that are registered, preserving their consent, while at the same time allowing only originative transactions that are registered to have legal effect against third parties, potentially eliminating the information asymmetry. Consequently, when ascertaining whether the company has complied with its originative transactions, third parties can rely on publicly registered originative transactions. Informal solutions based on appearance, such as the doctrine of apparent authority in the United States, manage this tradeoff by giving legal effect to the reasonable beliefs of third parties as to the authority of agents, based on public knowledge of the agents' legal authority. As a consequence, these solutions also allow third parties to rely on evidence of originative transactions presented to them by company agents during the subsequent contractual process.

${ }^{13}$ See, e.g., Restatement (Third) of Agency $\S 2.03$ (2006). 


\section{B. Due Diligence and Legal Opinions}

As part of the process of entering into a subsequent transaction, third parties will undergo a "due diligence" review. The due diligence review involves (among other things) locating, authenticating, and interpreting evidence of the company's originative transactions in order to verify that a court will enforce the subsequent transaction as the third party intended. Usually, third parties involve lawyers to conduct this review for them and further, to create a report, called a transactional legal opinion (herein, "legal opinion") detailing legal issues concerning the likely enforcement of the subsequent transaction. Legal opinions contain a series of assertions, qualifications, and assumptions, and are typically perceived as an added safeguard that increases the probability that the due diligence review was conducted accurately. ${ }^{14}$ Legal opinions have played a role in business transactions in the United States for more than a century, and have become standard practice for high value, purely domestic transactions in the United States, international transactions where at least one party is from the United States, and increasingly, purely domestic transactions in foreign countries. ${ }^{15}$

${ }^{14}$ See Donald W. Glazer \& Stanley Keller, A Streamlined Form of Closing Opinion Based on the ABA Legal Opinion Principles, 61 Bus. LAw. 389, 389-92 (2005). It has been suggested, with respect to the United States, that legal opinions often do not provide incremental informational value that justifies their cost, and that this excess cost is driven by (1) excess demand by requesting lawyers, who attempt to avoid reputational penalties for perceived professional incompetence by requesting non-cost justified, but entrenched, excessive legal opinions, and (2) an excess supply of legal opinions by companies who wish to avoid being perceived, through an adverse selection mechanism, as being on an extreme-low end of the contracting quality spectrum, see Barnett, supra note 9. Observe that excess lawyer demand and excess company supply of opinions is partly consistent with our theory: the ability of lawyers and notaries to capture rents may lead to both registry underdevelopment as well as unnecessary or defensive lawyering, see ARRUÑADA (2012), supra note 7 . To the extent that defensive lawyering is entrenched as an industry standard for contracts, companies may feel the need to provide opinions to signal a base level of contracting quality. Something similar to the unnecessary or defensive lawyering argument has been claimed with respect to title insurance, which plays a parallel function in the field of real property, id. at $188-91$.

15 Although the history of legal opinion practice in the United States prior to the 1970 's is not extensively documented, some authors have suggested that it began as an outgrowth of municipal finance transactions in the railroad context, where railroad bond buyers sought confirmation that municipal authorities had obtained the requisite authority to obligate the municipal government to the bond contract, see Robert W. Gordon, Legal Thought and Legal Practice in the Age of American Enterprise: 1870-1920, 131, note 40, in Professions and Professional Ideologies in America (Gerald L. Geison ed., 1983) (citing Charles Fairman, Reconstruction and Reunion, 1864-88, Part One, in 6 Oliver Wendell Holmes Devise: History of the Supreme Court in the United States, 918 (1971)). For evidence that legal opinions are increasingly popular in domestic transactions of foreign countries, see GRUSON \& HUTTER, supra note 4, at xxviii, citing Nicolas Grabar 
Each portion of a legal opinion that addresses a particular legal issue is herein referred to as an "assurance."

The International Bar Association (2003) provides model legal opinion language for a legal opinion used to support a bank loan transaction ("Credit Agreement") between a New York bank and a foreign corporate borrower (see a description of this dataset in Section III). ${ }^{17}$ Typically, the lawyer who represents the corporate borrower will draft the legal opinion and deliver this opinion to the lender and the lender's lawyer prior to closing the contract. Within the text of the legal opinion, the authoring lawyer includes a formal statement acknowledging that a due diligence review was conducted:

We have acted as counsel for the Borrower in connection with the preparation, execution and delivery of, and the initial Borrowing made under, the Credit Agreement. In that connection, we have examined: (a) A counterpart of the Credit Agreement, executed by each of the parties thereto; (b) The documents furnished by the Borrower pursuant to Section of the Credit Agreement and listed in Exhibit B hereto; (c) The charter of the Borrower and all amendments thereto (the 'Charter'); (d) The by-laws of the Borrower and all amendments thereto (the 'By-laws'); and (e) Such other documents and such treaties, laws, rules, regulations and the like as we have deemed necessary as a basis for the opinions hereinafter expressed. In such examination we have assumed the genuineness of all signatures, the authenticity of all agreements, certificates, instruments and documents submitted to us as originals and the conformity to the originals of all agreements, certificates, instruments and documents submitted to us as copies. ${ }^{18}$

Based on this due diligence review, the borrower's lawyer then makes a series of legal assurances that attempt to predict how a judge will enforce the Credit Agreement in the event of a future dispute:

\& Albert S. Pergam, International Opinions, 109, in M. JOHN STERBA, JR. (ED.), DRAFTING LEGAL OPINION LETTERS (2d ed. 1992), "In public offerings of securities in Europe, for example, or in large project finance arrangements, opinion letters are delivered to third parties when Americans are nowhere to be found. More generally, the very fact that a transaction is international, and thus that parties are unfamiliar with one another's legal environments, is increasingly a reason to require an opinion."

${ }^{16}$ What we call "assurances" are commonly referred to as "opinions" among legal opinion practitioners, even though they are one of many sections within one legal opinion letter. For example, what GruSOn, HUTTER \& KUTSChERA, supra note 4, refers to as the corporate action "opinion" is one of several sections of the model legal opinion letter presented, which also contains many other sections addressing other legal issues. For expositional simplicity, we refer to sections within a legal opinion letter addressing different legal issues as "assurances," rather than "opinions," to distinguish them from the legal opinion letter itself.

${ }^{17} \mathrm{Id}$.

${ }^{18} \mathrm{Id}$. at 29 (emphasis added). 
Based upon the foregoing examination and assumptions and upon such investigation as we have deemed necessary, and subject to the qualifications set forth herein, we are of the opinion that: (a) The Borrower is a corporation duly incorporated, duly organized, validly existing [and in good standing] under the laws of the Borrower's country, (b) The Borrower (i) has the corporate power to execute, deliver and perform the Credit Agreement and the Notes, (ii) has taken all corporate action necessary to authorize the execution, delivery and performance of the Credit Agreement and the Notes, and (iii) has duly executed and delivered the Credit Agreement and the Notes... ${ }^{19}$

These assurances address various legal issues. For example, an assurance that the borrowing company is "duly incorporated, duly organized, validly existing, and in good standing," informs the lending party that the company exists as a legal entity in the borrower's jurisdiction. A statement that the company has the "corporate power to execute, deliver, and perform" the lending agreement assures the lender that the company has not assented to the contract ultra vires. Similarly, an assurance that the borrower has taken "all corporate action necessary to authorize the execution, delivery and performance" of the lending contract asserts that the company has conducted all necessary procedures to bind the company to the contract, i.e. it has complied with its authority-delegation procedures, legally transferring the authority to bind itself to a particular contract from the firm (principal) to the contract-signing agent. For example, if it is necessary for the company to pass a resolution in order to bind itself to a lending contract, this assurance asserts that this resolution was passed according to the procedures outlined in the company's charter and bylaws (a copy of this resolution is also typically presented prior to the contract's closing). ${ }^{20}$

\section{Testable Prediction}

If our interpretation of the role and registries and legal opinions is correct, for certain classes of legal opinion assurances, more extensive public registration of originative transactions should be associated with less extensive due diligence reviews conducted by third parties prior to entering

\footnotetext{
${ }^{19}$ Id. (emphasis added).

${ }^{20}$ For elaboration on the meaning of these assurances in the international transaction context, see GRUSON, HUTTER \& KUTSCHERA, supra note 4, at 80-81 (due incorporation), at 93-94 (due organization), at 100-101 (validly existing), at 120-124 (good standing, corporate power, corporate action).
} 
into subsequent transactions. This is based on the idea that, for these assurances, if originative transactions are not verified by the registry, they must still be verified by other means. The due-diligence process undertaken to prepare these legal opinion assurances serves as a substitute for verification by the registry.

There are many different classes of legal opinion assurances, and only some rely on the authentication of originative transactions. For example, as previously introduced, the corporate action assurance speaks to whether the company has followed all authority-delegation procedures specified in its originative transactions. Naturally, as part of the due diligence process necessary to render the corporate action assurance, legal opinion preparers must review and authenticate company originative transactions. We label assurances that require this type of review as AOD (authentication of originative transaction) assurances. Alternatively, the due diligence process for some classes of assurances does not depend on authenticating originative transactions. We label these assurances as NOD (no originative transaction) assurances. For instance, for the "enforceability of foreign judgments" assurance, the opining lawyer indicates whether it is likely that a judgment obtained on the agreement in a jurisdiction foreign to his own would be enforced in his jurisdiction. In the context of a New York bank loan to a foreign company borrower, this could involve the New York bank receiving a judgment against the foreign company borrower in New York and seeking to enforce this judgment in the foreign company borrower's home jurisdiction. The due diligence process necessary to produce this assurance involves a detailed review of the loan agreement and of the law of the company's jurisdiction. It does not directly involve authentication of the company's originative transactions.

Keeping this distinction in mind, we propose the following:

Proposition. Using the length of comments on model legal opinions as proxies for the extent of the due diligence review within a jurisdiction, for AOD assurances, we expect the presence of longer legal opinion comments in jurisdictions where originative transactions are not publicly registered or are registered incompletely.

Alternatively, since the due diligence process for NOD assurances does not depend on the authentication of originative transactions, we do not expect to find a relationship between legal opinion comments for these assurances and the registration of originative transactions. In Section IV.B, Table 5, we use this theoretical prediction for NOD assurances to develop a "placebo" test that confirms the robustness of our main results. 
Before running a quantitative test, we will first illustrate in Section II the tradeoff between ex ante registration and ex post legal work by comparing qualitatively two extreme types of corporate registries: those of the United States and Germany.

\section{Qualitative Analysis of Two Extreme CASES: Business REGISTRIES IN THE UNITED STATES AND GERMANY}

Registries in different jurisdictions have historically developed variations in registry requirements. These variations create an opportunity to test for the presence of a tradeoff between the extent of ex ante registration procedures and the extent of the due diligence process used to support the creation of subsequent transactions, ex post to registration. Typically, all registries require the registration of corporate charters (or corporate charter equivalents) and their amendments. However, beyond this basic requirement, registries differ according to which additional originative transactions must be registered (including company bylaws, board and shareholder resolutions, and director and officer appointments) and whether amendments to these originative transactions must be filed.

The organization of a "maximalist" registry, such as that of Germany, takes the following form: the charter, bylaws, all relevant board and shareholder resolutions, the identity and sample signatures of all major classes of legal representatives of the company, and all amendments to these originative transactions must be registered. In these jurisdictions, in almost all cases, no unregistered originative transaction or company representative can be used against outside parties entering into subsequent transactions with the company in the event of a legal dispute.

Conversely, a "minimalist" registry, such as those in the United States following section 1.25(d) of the Model Business Corporation Act, ${ }^{21}$ which since 1984 has treated the role of company registries as purely ministerial, takes the following form: only the charter, as well as amendments to the charter, must be registered for legal validity against third parties. Consequently, in the event of a legal dispute, other originative transactions (such as bylaws and bylaw amendments, board and shareholder resolutions, and appointments of legal representatives of the company, including changes in directors and officers) could conceivably be used against third

\footnotetext{
${ }^{21}$ Model Bus. Corp. Act. ANn. (AM. BAR Ass'N 2008).
} 
parties entering into subsequent transactions with the company even if such originative transactions remained unregistered. Often, these jurisdictions with a "minimalist" registry offer informal protections based on appearance, such as the doctrine of apparent authority in the United States, as a substitute for registry protection. These informal solutions allow parties to rely on unregistered originative transactions presented to them by the company during the contract-formation process. Understandably, these informal solutions do not fully eliminate the information asymmetry suffered by third parties, particularly in the context of large (lending) transactions. For instance, the TriBar Opinion Committee claimed that "there is little interest in commercial circles in establishing that the [Borrower]...is bound as a result of apparent authority, rather than actual authorization by the [Borrower].",22

The expected tradeoff is this: as a country's registration system more resembles that of Germany, which represents an extreme case given that unregistered originative transactions generally cannot be used against third parties, the due diligence review process used to support subsequent transactions will be less extensive, on average, than this process in countries with registration systems that resemble those jurisdictions in the United States which allow companies to enforce unregistered originative transactions against third parties. The reason for this is that in countries like Germany, the due diligence review for a third party will typically involve merely receiving evidence of originative transactions from the business registry, authenticated by the registry (example: a registry-certified copy of the company charter). As long as the registry is reliable to future enforcers (judges), third parties can fully rely on only this registry-provided evidence of originative transactions. Alternatively, in countries such as the United States, the due diligence review for a third party will typically involve acquiring evidence of originative transactions from both the business registry (in the case of the company charter), as well as from the company (for bylaws, board and shareholder resolutions, and primary agent appointments). Because the company's interests will likely be adverse to the third party in the event of a future dispute, accumulating this evidence directly from the company usually involves more elaborate procedures intended to support a possible apparent authority defense. For example, third parties will often seek various officer certifications attesting to the authenticity of company-provided documents.

As an illustrative example, we consider the due diligence review conducted by lawyers in the United States versus lawyers in Germany when they write corporate action assurances, which detail whether a corporate

\footnotetext{
${ }^{22}$ TriBar Opinion Committee, Legal Opinions to Third Parties: An Easier Path, 34 Bus. LAW. 1891, 1912 (1979).
} 
officer is authorized to execute a contract on a company's behalf. In a typical state in the United States, a corporate officer is "actually" authorized to execute a contract on a company's behalf if the agreement is approved or authorized, "in a manner consistent with the applicable company statute and the company's charter and by-laws, by the proper body or bodies (stockholders, directors, or board committee), by the required vote at a properly called and held meeting (or by appropriate written consent).",23 According to the TriBar Opinion Committee, a corporate action assurance also signals that "the persons identified in the agreement as signatories had actual authority to execute the agreement on behalf of the company, that all required signatures were obtained and that the company delivered the executed agreement (or caused it to be delivered) in a manner permitted by applicable law." 24 Although other doctrines, such as apparent authority and implied authority are available to generate corporate authorization, parties to large value transactions (the transactions where legal opinions are most common) tend to demand assurances that the transaction was actually authorized. $^{25}$

The due diligence review supporting the corporate action assurance in the United States therefore involves reliance on unregistered originative transactions (in particular, bylaws and board resolutions). Often, as stated by the TriBar Opinion Committee, the assurance is delivered after review of "a certificate signed by the corporate secretary stating that (i) a meeting of the board of directors, at which a quorum was present, was held on a specified date on notice duly given and (ii) at the meeting a resolution authorizing the agreement was adopted by the required vote," and an investigation that there has been no substantive action affecting the resolution since then. ${ }^{26}$ Additionally, legal opinion writers would inspect a copy, certified by the Secretary of State, of the company's articles of association and an up-to-date copy of the company's bylaws certified by the company's secretary, as well as "miscellaneous other certificates attesting to the validity of certain signatures, to the identity of certain officers, and to the up-to-date character of the other documents." 27 Although Clark's example referred to the sale of substantially all of a corporation's assets, the analysis is applicable to a major corporate loan.

The TriBar Opinion Committee acknowledges potential problems with using unregistered sources prepared by parties interested in the transaction:

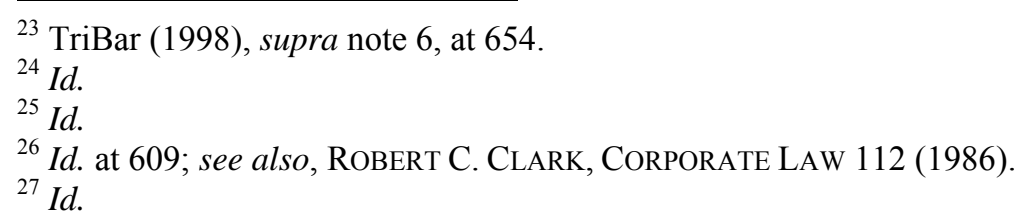


The opinion preparers could also (but almost never do) interview the corporate secretary or obtain certificates from one or more participants in the meeting. Even if that were done, those who purported to participate in the meeting might claim that the meeting was held, even though it was not. The falsity of their claim might, in turn, be revealed by some further step - for example, locating witnesses who are aware of what really happened. In almost every situation the possibility that the information certified is not true would remain despite efforts to look beyond the information provided to that point. ${ }^{28}$

Alternatively, legal opinion writers in Germany rely more heavily on publicly registered information. The two primary forms of company in Germany are the Aktiengesellschaft ('AG') (public company) and the Gesellschaftmit beschränkter Haftung (' $\mathrm{GmbH}$ ') (private company with limited liability). The basic documents for the AG and $\mathrm{GmbH}$ are the 'Satzung' and the 'Gesellschaftsvertrag', respectively. The contents of each are similar to those of the charter and by-laws of U.S. corporations. Both must be filed with a registration court as a pre-requisite to incorporation, and upon registration, important contents of the Satzung or the Gesellschaftsvertrag are published by the company register ('Handelsregister'). ${ }^{29}$ Further, all amendments to the Satzung or the Gesellschaftsvertrag only become effective with respect to third parties when their existence is registered, and, with minor exceptions, ${ }^{30}$ copies of these amendments must also be filed. Moreover, certain corporate officers are endowed with corporate authority as a matter of law. Each corporation must designate a class of officers with unlimited authority whose names are registered with the company register. Further, these officers are generally allowed to represent the corporation jointly unless the Satzung or Gesellschaftsvertrag specifies otherwise. In addition, there are classes of officers of more limited authority, one of which need not be registered.

Therefore, in most transactions, legal opinion writers can determine the extent of a corporate officer's authority directly from the German company register. Further, with rare exceptions, ${ }^{31}$ third parties are permitted to rely on the statutorily defined authority of officers to act on behalf of the corporation, and this authority is not limited with respect to third parties by unregistered rules of the company. ${ }^{32}$

${ }^{28}$ TriBar (1998), supra note 6, at 609.

${ }^{29}$ GRUSON, HUTTER \& KUTSCHERA, supra note 4, at 60.

${ }^{30}$ Id. at 71 .

${ }^{31}$ These exceptions include, for instance, special statutorily defined transactions or cases in which the third party was or should have been aware of an abuse of an officer's authority to bind the corporation, see GRUSON, HUTTER \& KUTSCHERA, supra note 4, at 133.

${ }^{32}$ Id. at $132-133$. 
Given these differences between registration requirements in the United States versus those in Germany, we would expect that the due diligence review process supporting the corporate action assurance in countries like the United States will be more extensive, on average, than the due diligence review process supporting the corporate action assurance in countries like Germany. As a proxy for the extent of the due diligence review process, we use the length of the legal opinion comment related to the corporate action assurance, which describes this process, by country. We therefore expect that these comments will be longer, on average, in countries like the United States as compared with comments in countries like Germany.

\section{DATA}

To test this proposition in a more general way, we built a dataset on legal opinions, drawn from a published report created by the International Bar Association, which details model opinion language used to support an international transaction. This report was constructed from elicited responses of lawyers from around the world, and it is the authoritative reference for drafters of legal opinions of this type in international transactions. ${ }^{33}$ It presents model opinion language for a loan by a New York bank to a foreign company borrower from the U.S. lawyer's perspective, followed by comments written by lawyers from 25 other countries, including: Argentina, Australia, Austria, Belgium, Brazil, Canada, Colombia, Czech Republic, Denmark, Finland, France, Germany, Greece, Hungary, Ireland, Italy, Japan, Luxembourg, The Netherlands, South Africa, South Korea, Spain, Switzerland, the United Kingdom and Venezuela. ${ }^{34}$ These comments provide a detailed examination of the legal interpretation of and customary due diligence review needed to render each assurance of the model opinion in a given country. ${ }^{35}$

The International Bar Association (2003) report provides a complete list of country comments for two classes of AOD (authentication of originative transaction) assurances: the corporate existence assurances (due incorporation, due organization and valid existence) and the due

\footnotetext{
${ }^{33}$ See generally, id.

${ }^{34}$ The Subcommittee chose to provide a model opinion and comments for a loan agreement opinion "because that opinion contains many of the opinion clauses which are also found in legal opinions rendered in connection with other types of agreements," Id. at 26.

${ }^{35}$ See generally, id.
} 
authorization and execution assurances (corporate action, corporate power). ${ }^{36}$ It also provides comments for two NOD assurances: the remedies assurance and the enforceability of judgments assurance. For the main empirical exercise, we focus on the legal opinion comments for the corporate action assurance ${ }^{37}$ from the International Bar Association (2003). ${ }^{38}$ For the placebo tests, we use the data available for both NOD assurances: the remedies assurance and the enforceability of judgments assurance. Data for the remaining assurances was excluded due to a lack of institutional variation in the registration of originative transactions across jurisdictions or the inapplicability of the assurance across a large number of jurisdictions. ${ }^{39}$

${ }^{36} I d$.

37 This assurance is sometimes called the "due authorization" opinion in the practitioner literature, although this term is ambiguous: it may include an assessment of whether the firm acted ultra vires, i.e. it may subsume a corporate power assurance, defined in Part I.B, supra. See id. at 122-123.

${ }^{38}$ Id. at $123-145$.

39 The due incorporation assurance typically speaks to whether all necessary formalities have been met to guarantee the legal existence of the firm. In all jurisdictions represented in the study (except for Canada (Ontario)) legal existence (with respect to third parties) begins upon company registration with the applicable company register or court. In other words, in every jurisdiction except Canada, no unregistered originative transactions can be used to deny the legal existence of a registered company. Therefore, this assurance does not provide the needed differentiation in registration practices to conduct our empirical test. The "due organization" assurance was not considered because it is redundant to the "due incorporation" assurance in all jurisdictions except for Belgium, Canada (Ontario), Greece, The Netherlands, and the United States. The "valid existence" assurance was not considered due to a lack of suitable data concerning the registration and legal effects of dissolution in the complete sample of countries studied. The corporate power assurance addresses whether the company has the legal capacity to enter into the contract. If a company does not have this capacity, it has acted ultra vires. The ultra vires defense is rare in the United States and many other jurisdictions in the sample, see id. at 122 , “...we would all agree that the defense of ultra vires [in the United States] is a difficult one..." also see the discussion and country comments, id. at 122-141. As a result, the length of these comments in the GRUSON, HUTTER \& KUTSCHERA publication is short relative to those attributable to the corporate action assurance, and there is very little differentiation among jurisdictions. As a robustness exercise, we combined the length of the corporate power and corporate action assurances into one dependent variable and conducted all empirical tests using this dependent variable. This corresponds to testing our theory on what is called the "due authority" assurance, which often combines the contents of the corporate power and corporate action assurances, see Jonathan C. Lipson, Price, Path \& Pride: Third-Party Closing Opinion Practice Among U.S. Lawyers (A Preliminary Investigation), 3 BERKELEY BUS. L.J. 59, 72-75 (2005) for an introduction to the due authority opinion. The results (available upon request) are very similar to those reported in our primary results, which utilize a dependent variable based only on the corporate action assurance. 
The corporate action assurance addresses whether the particular company agent executing the agreement possesses the requisite legal authority to enter into a contract on behalf of the company. This assurance is a commonly requested and important assurance for legal practitioners. ${ }^{40}$ In order to render this assurance, a legal opinion writer will typically review a variety of originative transactions, such as the charter, bylaws, and board and shareholder resolutions, as well as any registered agent appointments (such as director appointments). For example, a company charter may set guidelines under which bylaws are established, while bylaws may set voting procedures for director appointments as well as majority and quota requirements for binding the company to large contracts. Further, a director resolution may authorize a particular company agent to execute a particular contract. Each of these originative transactions represents potential sources of a company agent's legal authority to enter into a contract on behalf of the company.

For this corporate action assurance, we collected the following pieces of information: (1) which originative transactions make up the necessary documentary investigation for rendering this assurance in a given country, (2) whether these originative transactions (and their amendments) are publicly registered, and (3) the length of the legal opinion comments for this assurance, by country. This information was coded as follows. To capture the "extent" of public registration, we recorded which of three classes of originative transactions in each jurisdiction can create or modify the legal authority of company agents to enter into a subsequent transaction on the company's behalf. The three classes of originative transactions include: a) charters and bylaws, b) board or shareholder resolutions that are needed to bind the company to contracts, and c) evidence of appointments for primary company agents (such as directors). Then, we recorded whether each of these classes of originative transactions is publicly registered. Public registration is defined as whether the class of originative transactions (and amendments to these transactions) must be publicly registered in order to have legal effect against third parties. In other words, if a company could enforce a class of unregistered originative transaction against a third party (notwithstanding the presence of an informal solution based on appearance), we recorded it as "unregistered."

\footnotetext{
40 "Lawyers overwhelmingly characterize [the due authority opinion] as adding informational value," id. at 75. "[The due authority opinion] is a simple, uncontroversial opinion," id. at 72, and appears to have "the deepest historical roots in third-party closing opinion practice," id. at 73. Further, in the case of a loan, "it is critical to the reasonable expectations of the lender that the borrower has the authority to borrow (and repay) the loan..." id. at 75 .
} 
Table 1 summarizes the data and the variables. The first variable, AllReg, is a zero-one indicator achieving a score of one if, in a given jurisdiction, all of the three classes of originative transactions are publicly registered, and zero otherwise. The second variable, RegScore, assigns a registration score to a particular jurisdiction by assigning one point for each of the three classes of originative transactions that is publicly registered (lowest score, zero; highest score, three). For example, a jurisdiction that mandates the registration of charters and bylaws (one point), all board and shareholder resolutions that are needed to bind the company to a subsequent transaction (one point), and all new director appointments (one point) receives the maximum RegScore value of three. In addition, in order to study the effect of the registration of originative transaction classes separately, we created an indicator for each class: CharterBylaws, Resolutions, and PrimaryAgents. Each of these indicators takes a value of one if the class of originative transaction is registered, zero otherwise. Finally, we used three control variables. The first is a zero-one indicator of the legal origin of a jurisdiction's commercial code (one if French or German Commercial Code, zero otherwise). ${ }^{41} \mathrm{We}$ use this variable to control for general differences between civil and common law jurisdictions that might independently produce variation in legal opinion comments. Secondly, we use a zero-one indicator of E.U. affiliation to control for any effects of E.U. directives related to registration procedures. Finally, we control for the $\log$ of per capita $\mathrm{GDP}^{42}$ by jurisdiction, since some authors have argued for the importance of a country's size as a determinant of particular institutional bundles. ${ }^{43}$ The primary dependent variable, Length_Act, measures the length of the legal opinion comments (number of lines), by jurisdiction, for the corporate action assurance.

Annex 1 provides a detailed example of how we built the indexes, and Annex 2 describes the entities and governing documents studied in each country.

\footnotetext{
${ }^{41}$ Data obtained from Rafael La Porta, Florencio Lopez-de-Silanes, Andrei Shleifer, \& Robert W. Vishny, Law and Finance, 106 J. POL. ECON. 1113 (1998) (variable code: "civ_com"), available at http://www.economics.harvard.edu/faculty/shleifer/dataset.

${ }^{42}$ GDP data collected from the World Bank, available at http://data.worldbank.org/indicator/NY.GDP.PCAP.CD.

${ }^{43}$ See, e.g., Djankov et al., supra note 8, at 23.
} 


\section{RESULTS AND INTERPRETATION}

\section{A. Results}

The primary results of the OLS regressions with respect to the "corporate action" assurance are listed in Tables 2 and 3. Table 2 shows the relationship between the registration of primary originative transactions and the length of legal opinion comments related to the corporate action assurance. Equation 1 (Table 2) shows that in jurisdictions where all originative transactions are registered, corporate action legal opinion comments are 7.340 lines shorter, on average, and this estimate is statistically significant at the $10 \%$ level. This result is robust to the addition of controls in Equation 3 (Table 2). When controlling for civil law origin, E.U. membership, and the log of per-capita GDP, countries that register all originative transactions have legal opinion comments that are 7.709 lines shorter, and this result is also statistically significant at the $10 \%$ level. The results are similar when we use a different measure of registry strength as the independent variable: a registration score that records the number of originative transaction classes that are registered. As shown in Equation 2 (Table 2), the registration of an additional originative transaction class is associated with legal opinion comments that are 2.704 lines shorter, although this result is not statistically significant. However, when controls are added, the point estimate becomes larger and statistically significant at the $10 \%$ level. This result is displayed in Equation 4 (Table 2). In this specification, the registration of an additional originative transaction class is associated with legal opinion comments that are 4.944 lines shorter.

These differences are economically significant. For example, the registration of all originative transactions in a jurisdiction is associated with legal opinion comments that are 0.776 standard deviations shorter (without controls) and 0.815 standard deviations shorter (with controls), where the standard deviation of legal opinion comments is 9.456 lines (and the mean number of lines is 21.6). Similarly, the registration of one additional originative transaction class is associated with legal opinion comments that are 0.286 standard deviations shorter (without controls) and 0.523 standard deviations shorter (with controls).

Table 3 presents regressions that use, as the primary independent variables, indicators for the registration of originative transactions by class, rather than the aggregated registration variables presented in Table 2 . Disaggregating the registration indicators by originative transaction class 
shows that the registration of charters and bylaws has the most important association with legal opinion comments in our sample. As shown in Equations 5 and 8 (Table 3), the registration of both charters and bylaws in a jurisdiction is associated with legal opinion comments that are 11.070 lines (1.170 standard deviations) shorter without controls (Equation 5) and 14.590 lines (1.543 standard deviations) shorter with controls (Equation 8), and both of these coefficients are statistically significant at the $1 \%$ level. The magnitudes of these coefficients are much larger and the coefficients are more statistically significant than those based on the aggregated registration variables in Table 2. This is consistent with the comparably weaker associations of the registration of the other originative transaction classes with legal opinion comment length, which make the results based on aggregated indicators weaker. As shown in Equations 6, 7, 9 and 10 (Table 3 ), although the point estimates on the coefficients for the registration of corporate resolutions and the identity of corporate officers are of the expected sign (registration is associated with shorter legal opinion comments), these coefficients are smaller than those on the charters and bylaws indicator and are not statistically significant at the $10 \%$ level.

It is important to note that for all of the regression results presented in Tables 2-5, the United States was excluded from the sample. We did this because of the structure of the International Bar Association (2003) report, which, for most assurances, uses the U.S. comment to more fully introduce discussions elaborated on within the individual country comments. As a consequence, the lawyer comment for the U.S. is an outlier for all quantitative tests in our sample (the U.S. comments are much longer than all other comments). Because the U.S. has both the longest lawyer comments and the weakest registry practices in the sample, excluding the U.S. from the sample biases the results presented in Tables 2 and 3 towards zero. $^{44}$

\section{B. Robustness and Interpretation}

In interpreting these results, it is necessary to consider two primary issues. First, are legal opinion comment lengths a good proxy for transaction costs? Second, if they are a good proxy, can we interpret the measured tradeoff as causal-i.e., does reliable registration of originative transactions lower transaction costs associated with legal opinions?

\footnotetext{
${ }^{44}$ Results including U.S. data are available from the authors.
} 
Our transaction cost interpretation of the results relies on the extent to which legal opinion comment length proxies for transaction costs. Given standardization in international legal opinion practice and the importance of the International Bar Association (2003) book as an industry standard resource for practitioners, it is likely that the due diligence process suggested by lawyers in these comments is similar to the due diligence process conducted in the standard or average transaction in each jurisdiction. Moreover, there is evidence from the legal practitioner literature that suggests the extent of the due diligence process is an important driver of legal opinion costs. ${ }^{45}$ Although comparing these results to those obtained from more direct measures of legal opinion costs would be ideal, it is not clear these alternative measures would be superior in measuring the sensitivity of costs to the registration of originative transactions. This is primarily because our proxy allows us to study legal opinion assurances in a disaggregated manner. Legal opinions typically include many assurances, only some of which are related to the registration of originative transactions. Further, based on discussions with legal practitioners involved in opinion practice, if contractual closing costs attributable to legal opinions are itemized, costs are typically not disaggregated at a level that would allow for identification of the effect of originative transactions on individual assurances. For example, legal opinion costs are usually itemized at the level of i) the entire opinion or ii) the entire contribution of a particular legal team. An assurance-by-assurance breakdown is not typically recorded. This suppresses the sensitivity of direct cost data to variations in the registration of originative transactions, since direct cost data includes costs attributable to assurances that we would not expect to be related to registration practices. Additionally, direct legal opinion costs are more likely to vary in different countries (and in different cities within countries) for a series of reasons unrelated to the registration of originative transactions, including jurisdictional differences in: the average market power of borrowers, average transaction complexity and size, relative market power of lawyers, etc. Therefore, to use these direct costs meaningfully, it would be necessary to collect a large sample with detailed transactional and institutional data by jurisdiction to allow us to control for these factors. Since most legal opinion cost data is confidential, collection of this type of dataset seems infeasible. Studying the extent of the due diligence process directly does not completely abstract from the abovelisted confounders; however, the tradeoff measured is much more targeted. Specifically, our proxy for transaction costs measures only the portion of transaction costs attributable to rendering the corporate action assurance,

${ }^{45}$ See California State Bar, supra note 5, at 929 and TriBar (1998), supra note 6, at 
and our empirical exercise seeks to quantify the tradeoff between the size of this portion of transaction costs and the registration of originative transactions.

A second issue is that of causality. Even if legal opinion comments serve as a reasonable proxy for the portion of transaction costs considered, can the results be confidently interpreted as causal? In cross-sectional, cross-country regressions, one obvious danger is that there may be many institutional differences that can account for the observed relationship between registration and the length of legal opinion comments. This concern is partly addressed by our use of appropriate control variables. A long literature has documented the institutional differences between civil law-origin countries and common law-origin countries and attempted to quantify the economic consequences of these differences. ${ }^{46}$ To the extent that institutional differences are bundled by legal origin, controlling for legal origin allows us to compare differences in legal opinion lengths conditional on legal origin. As shown in Table 4 (Equations 11-13) dropping the five common law countries from the sample actually makes the coefficients on all originative transaction variables even more negative. The coefficient on the registration score variable (Equation 13) not only becomes more negative by a factor of 1.7 as compared with the coefficient on the same variable in Equation 4 (Table 2), but it also becomes statistically significant at the 5\% level rather than at the $10 \%$ level. This provides some evidence that our results are not driven purely by differences between civil and common-law countries. ${ }^{47}$ Similarly, the results are robust to controlling for E.U. affiliation, which also provides a common set of institutions in the form of E.U. directives. Table 4 (Equations 14-16) shows that, when only E.U. affiliated countries are included in the sample, the coefficients and statistical significance of the originative transaction variables change little as compared with those obtained from the full sample. ${ }^{48}$ Finally, many studies have used the log of per-capita GDP as a

\footnotetext{
${ }^{46}$ For an introduction to these differences, see KONRAD ZWEIGERT \& HEIN KöTZ, AN InTRODUCTION to Comparative LAW (3rd ed. 1998). Also see Rafael La Porta, Florencio Lopez-de-Silanes, \& Andrei Shleifer, The Economic Consequences of Legal Origin, $46 \mathrm{~J}$. ECON. LiT. 285 (2008) for a survey of the literature studying the economic consequences of legal origin.

${ }^{47}$ Arruñada (2003), supra note 9, presents a similar result in the property registries context, finding that legal origin (common law versus civil law) is not statistically significantly associated with the choice of property titling system.

${ }^{48}$ Since there are only five common law countries in the sample, a similar robustness exercise was not performed on only common law countries due to the small remaining sample size. Similarly, there are only ten non-E.U. countries in the sample, and running the same regressions including only these countries resulted in very statistically imprecise coefficients, with one coefficient (AllReg) of the wrong sign. With such a small sample of non-E.U. countries, it is difficult to interpret this result.
} 
control for the overall quality of institutions, since richer countries may demand different bundles of institutions than poorer ones. ${ }^{49}$ As shown in Tables 2 and 3, the results are robust to inclusion of this control.

Similarly, reverse causality-i.e., the possibility that extensive legal opinion practice induces weaker registry practices, rather than visa versais highly unlikely in all jurisdictions outside of the U.S. This is because, although legal opinion practice has a long history in the U.S., it is a rather new practice in other jurisdictions. ${ }^{50}$ On the other hand, corporate registration has a long history in most countries. ${ }^{51}$ Within the U.S., although corporate registries were in use before legal opinion practice became established, it is possible that the market power of lawyers could have made legal opinion practice more extensive while also suppressing the power and functions of corporate registries. However, regardless of whether this reverse causality story holds in the United States, it is not a concern for the presented results, since the United States was excluded in all regressions.

A final concern is that lawyers in jurisdictions that register few originative transactions may tend to write longer opinions generally, rather than in response to the lack of registered originative transactions as predicted by our theory. This could be due to general cultural or historical differences in legal practice. For example, perhaps lawyers in jurisdictions like the United States are simply more "thorough" than lawyers in other jurisdictions. If this is true, then we might expect that our registry measures would be related not only to the length of the corporate action comments, but also to the length of other comments, even those that our theory does not predict should be related to the registration of originative transactions (NOD assurances, defined in Part I.C). Table 5 presents the results of a placebo test intended to determine whether this concern is supported by the data. The International Bar Association (2003) publication contains a full set of legal opinion comments for two NOD assurances: the "conflict-oflaws" assurance, as well as the "enforceability of foreign judgments" assurance. The conflict-of-laws assurance, which is typically subsumed under the well-known remedies assurance, speaks to whether the governing law clause contained in the lending contract will be given effect in the borrower's jurisdiction. ${ }^{52}$ For example, if a New York bank lends to a foreign corporate borrower, the New York bank will generally insert a clause in the contract that dictates that the laws of New York will govern the interpretation of the contract's terms. The conflict-of-laws assurance

${ }^{49}$ See, e.g., Djankov et al., supra note 8, at 23.

${ }^{50}$ GRUSON, HUTTER \& KUTSCHERA, supra note 4, at 10.

${ }^{51}$ See the cases of France, Spain and the United Kingdom in ARRUÑADA (2012), supra note 7 , at $96-107$.

${ }^{52}$ See Gruson, HutTER \& KUTSCHERA, supra note 4, at 163-179. 
speaks to whether courts in the foreign borrower's country will accept that choice of governing law, or if instead this clause violates the foreign country's choice of law provisions or fundamental public policies. The enforceability of foreign judgments assurance addresses a related question: whether the foreign borrower's jurisdiction recognizes and enforces judgments (or arbitration awards) obtained in the New York lender's jurisdiction.

Importantly for our analysis, these assurances do not require the foreign borrower's counsel to investigate whether the foreign corporate borrower complied with internal corporate procedures governed by the originative transactions of the corporation. Instead, the foreign counsel must research his country's choice of law and foreign judgment enforceability provisions and compare them to the lending contract. Under our theory, the length of legal opinion comments related to these assurances should be unrelated to the registration of originative transactions. However, if the registration of originative transactions is somehow inversely related to the presence of more "thorough" lawyers in a jurisdiction, we would expect our registration measures to have the same relationship with the length of legal opinion comments for these NOD assurances as they had with the length of comments for the corporate action assurance (an AOD assurance). As shown by Table 5, neither of our registration strength variables is significantly related to the length of comments for the conflict-of-laws and the enforceability of foreign judgments assurances. Further, these registration variables do a very poor job of explaining variation in the length of these comments as indicated by low r-squared values, where the highest r-squared value is 0.07 (Equation 22) and the lowest is 0.004 (Equation 18). As shown by Table 5, the relationship between originative transaction registration and corporate action legal opinion comment length is not likely driven by the relative thoroughness of lawyers in countries that also weakly register originative transactions.

In summary, although we cannot rule out the possibility that unobserved variables or institutional differences are driving the results, it is reassuring that the results are not driven by differences in legal origin, E.U. affiliation, and economic wealth, the primary determinants of institutional bundles discussed in the literature. Further, due to the relatively recent emergence of legal opinion practice in all jurisdictions outside of the United States, reverse causality - that legal opinion practice drives registry practices rather than visa versa - is not a plausible story for our sample, which excludes the United States. Finally, a story that lawyers in weak registration jurisdictions are more "thorough" is not supported by the placebo tests conducted in Table 5. Based on these robustness checks and the targeted nature of our test (comparing the due diligence process for the corporate action assurance 
with registration of originative transactions), it is our conclusion that the most plausible story is a causal one: that extensive registration of originative transactions makes the process of authenticating these transactions less cumbersome.

\section{IMPLICATIONS AND DISCUSSION}

Our results confirm that differences in registry requirements and organization involve tradeoffs reflected in the behavior of lawyers that may impact contractual costs for companies. In countries with less stringent registration requirements, we find that legal opinion comments are longer, even after controlling for the legal origin, E.U. affiliation, and log per-capita GDP of each country.

This finding provides novel empirical support for the theoretical proposition that there are tradeoffs between more extensive registration procedures and transaction costs associated with subsequent transactions in the context of business registries, complementing analogous results in the context of property registries. ${ }^{53}$ Further, the presence of a tradeoff suggests that the work of certification intermediaries, either registries or legal services, is important for resolving informational asymmetries associated with verifying the contents of originative transactions. Specifically, we find evidence of a tradeoff between public and private certification intermediaries (registration and legal opinions, respectively). This evidence complements work studying the information-asymmetry-reducing role of certification intermediaries in other contexts. ${ }^{54}$ It is also related to work in the product quality context that studies the theoretical implications of different mechanisms for communicating product quality, including disclosure and signaling. ${ }^{55}$ Using the language of this literature, our findings show that the extent of legal intermediation supporting "voluntary" disclosure of originative transactions (via legal opinions) is higher (lower) in presence of weaker (stronger) "mandatory" disclosure of originative transactions (via public registration). It is interesting to note that the causes of the information-asymmetry we study are different than those typically studied. For example, in the context of financial intermediation of a loan transaction, the literature has focused on the superior information of borrowers (with respect to lenders) concerning the quality of their business projects, which predicts their future financial viability and ability to repay

${ }^{53}$ See ARRUÑAdA (2012), supra note 7, at 156-160.

${ }^{54}$ For a review, see Dranove \& Jin, supra note 10.

${ }^{55}$ See, e.g., Daughety \& Reinganum, supra note 9. 
the loan. ${ }^{56}$ Instead, we focus on the legal quality of the loan transaction and information asymmetry induced by superior knowledge on the part of the borrower with regards to its originative transactions.

The results further motivate more comprehensive empirical studies on the efficiency of more extensive (versus less extensive) registration. Our finding that there is a tradeoff between ex ante public registration requirements and ex post transaction costs does not determine whether public intervention results in overall efficiency gains. In other words, our findings do not address whether solutions that rely less on public registries, such as those found in the U.S., result in overall efficiency losses (or gains) relative to solutions that rely more on public registries, such as those found in Germany. It is possible that substituting stronger ex ante public registration for less ex post due diligence may result in higher overall costs for firms, to the extent that public registration is less efficient than lawyerprovided due diligence. Arguments that more extensive registration requirements may result in overall efficiency losses have taken three primary forms. The first suggests that, if the value of subsequent transactions is low, imposing strict registration requirements uniformly on all originative transactions may be inefficient. ${ }^{57}$ For example, in the U.S. patent context, Lemley argues that since most patents are never litigated or licensed, weak review of patent applications can result in overall efficiency gains if the costs of more stringent patent review at the U.S. Patent and Trademark Office are high enough. ${ }^{58}$ A second registry inefficiency argument points out that public actors or private interests may use public registration requirements as an opportunity to collect rents from firms or exclude competing firms from entering the market, respectively. ${ }^{59}$ Finally, registries may otherwise fail as reliable sources of information for future enforcers (judges) due to a lack of independence from private contracting parties or if public employees lack sufficient incentives to perform their duties competently. ${ }^{60}$

In the context of business registries, all of these arguments are plausible; however, validating each is a jurisdiction-specific empirical question. Our

\footnotetext{
${ }^{56}$ See, for example, Hayne E. Leland \& David H. Pyle, Informational Asymmetries, Financial Structure, and Financial Intermediation, 32 J. FIN. 371 (1977) and related work.

${ }^{57}$ See, e.g., Arruñada \& Garoupa (2005), supra note 9, who show in the property registry context how the socially optimal land titling system changes as the value of the underlying properties changes.

${ }_{58}^{5}$ See Mark A. Lemley, Rational Ignorance at the Patent Office, 95 Nw. U. L. REv. $1495(2001)$.

${ }_{59}$ See, e.g., Djankov et al., supra note 8.

${ }^{60}$ For a discussion of the effects of a lack of registry independence in the company context, see ARRUÑADA (2012), supra note 7, at 90-92. See also, id. at 215-228 for policy proposals for better structuring the incentives of both registry users and providers.
} 
results provide some evidence that there is a tradeoff between ex ante registration requirements and ex post transaction costs. The study of the overall efficiency gains of either system would need to more comprehensively account for the costs and benefits of public registration versus the costs and benefits of substitutes for public registration (such as the issuance of legal opinions) to determine efficiency gains. This type of study is outside of the scope of this paper and is an important avenue for further research. ${ }^{61}$

However, many important public policy initiatives have advocated the efficiency of weaker registries even in the absence of a complete characterization of the relative efficiency of strong versus weak registries. The largest of these initiatives is the Doing Business initiative created and maintained by the World Bank. ${ }^{62}$ This initiative collects information on regulatory procedures and costs associated with various tasks of business activity in a sample of 189 countries. ${ }^{63}$ The most relevant indicators for our study are the "Starting a Business" indicators, which seek to measure the cost, time, and number of procedures that an entrepreneur must incur to start a business in each jurisdiction. As pointed out by Arruñada (2007), these indicators measure mandatory registration costs (and voluntary registration costs incurred by a majority of entrepreneurs), but ignore tradeoffs between ex ante registration and ex post transaction costs. ${ }^{64}$

\footnotetext{
${ }^{61}$ Although this is an open question, in the context of business registries, it is not clear that lawyer-provided due diligence and legal opinions are efficiency-improving substitutes for registration. Lawyers issuing legal opinions typically add a series of qualifications meant to protect themselves from liability in the event that the assurances made in the opinion are erroneous, leaving much of the informational asymmetry experienced by contracting third parties intact, see TriBar (1998), supra note 6, at 597, for an introduction to qualifications in legal opinions; see generally, TriBar, Special Report of the TriBar Opinion Committee: The Remedies Opinion-Deciding When to Include Exceptions and Assumptions, 59 BUs. LAW. 1483 (2004), for a discussion of some standard qualifications and assumptions made in the context of a remedies opinion. For example, the model legal opinion in GRUSON, HUTTER \& KUTSCHERA (2003), supra note 4, contains the following qualifications concerning the examination and authentication of a company's originative transactions: "In such examination we have assumed the genuineness of all signatures, the authenticity of all agreements, certificates, instruments and documents submitted to us as originals and the conformity to the originals of all agreements, certificates, instruments and documents submitted to us as copies," at 29 (emphasis added).Determining which institutional arrangement is more efficient turns on whether the (potentially larger) costs of more extensive registration are more than offset by lower costs of originative transaction authentication at the time of contracting.

${ }^{62}$ World Bank, supra note 8 . Reports and data available at http://www.doingbusiness.org.

${ }^{63}$ For a list of the full set of Doing Business indicators as well as the methodology for their production, see $\mathrm{http}: / / \mathrm{www}$.doingbusiness.org/methodology.

${ }^{64}$ Arruñada (2007), supra note 1.
} 
Problematically, the indicators are then used to rank countries, and these rankings have been used as a factor in the allocation of international development aid, which has in turn induced countries to "simplify" their registry procedures in order to improve their chances of acquiring aid. ${ }^{65}$

The existence of tradeoffs between registration and transaction costs found in our study should provide reason for cautious application of policy prescriptions that seek to simplify registration requirements and rank countries based on the extent of ex ante public registration procedures. Although simpler registration can eliminate unnecessary or overly burdensome procedures, weaker registration of originative transactions may unintentionally increase costs of future company contracting, and these costs are not measured in the Doing Business Starting a Business indicators. That these costs are not measured makes ranking jurisdictions based only on ex ante registration procedures misleading. For example, based on the Doing Business Starting a Business indicators, in 2013, Germany was ranked as the $104^{\text {th }}$ best country to start a business while the United States was ranked as the $11^{\text {th }}$ best country to start a business. ${ }^{66}$ Given the analysis in Section II, this is not surprising: Germany imposes more extensive ex ante registration requirements than the United States. However, since we find that more extensive registration is associated with lower costs of verifying originative transactions prior to consummating subsequent transactions, it is not clear that Germany should receive a lower ranking than the United States, i.e. it is not clear that Germany has imposed a less efficient set of registration requirements. More generally, the presence of legal opinions as possible substitutes for registration requirements suggests that countries with weaker public registration requirements may have evolved private mechanisms to deal with the effects of these weaker requirements. Eliminating registry requirements in countries that have not evolved these mechanisms may have especially harmful effects on the costs of company contracting. At the very least, more empirical evidence concerning the tradeoffs between registration and contractual costs is needed to determine the effects of registry simplification policies.

\footnotetext{
${ }^{65}$ See Arruñada (2007), supra note 1, at 731-732, for a discussion of how international aid organizations have used Doing Business data to allocate international aid, and consequently, how countries have responded to these incentives by initiating registry simplification reforms.

${ }^{66}$ World Bank, supra note 8 , available at

http://www.doingbusiness.org/data/exploreeconomies/germany (for Germany), and http://www.doingbusiness.org/data/exploreeconomies/united-states (for the United States).
} 


\section{CONCLUSION}

In this article, we study the relationship between mandatory ex ante registration of formal company documents (such as charters, bylaws, and resolutions) and ex post transaction costs attributable to the creation of transactional legal opinions used to support large company contracts. To do so, we utilize data on company registration requirements from twenty-six countries and compare these requirements to a proxy for company transaction costs in these countries. Our proxy is the length of comments describing the due diligence process necessary to render a model transactional legal opinion in each country ("legal opinion comments"), collected from an authoritative report on international legal opinion practice produced by the International Bar Association. We find that in countries where registration requirements are less stringent, legal opinion comments are longer, even after controlling for commonly referenced determinants of institutional differences between countries, including legal origin, European Union affiliation, and the log of per capita GDP.

These findings provide novel evidence of a tradeoff between ex ante company registration requirements and ex post company transaction costs. They also provide reason for cautious application of policy prescriptions that seek to simplify registration requirements and rank countries based primarily on the extent of ex ante public registration procedures, such as the Doing Business reports of the World Bank. Instead, the presence of this tradeoff motivates more comprehensive studies of the overall efficiency of registration institutions that take both ex ante registration and ex post transaction costs into account. 


\title{
33 THE TRADEOFF BETWEEN EX ANTE AND EX POST TRANSACTION COSTS
}

\author{
VII. TABLES
}

TABLE 1. Description of Variables.

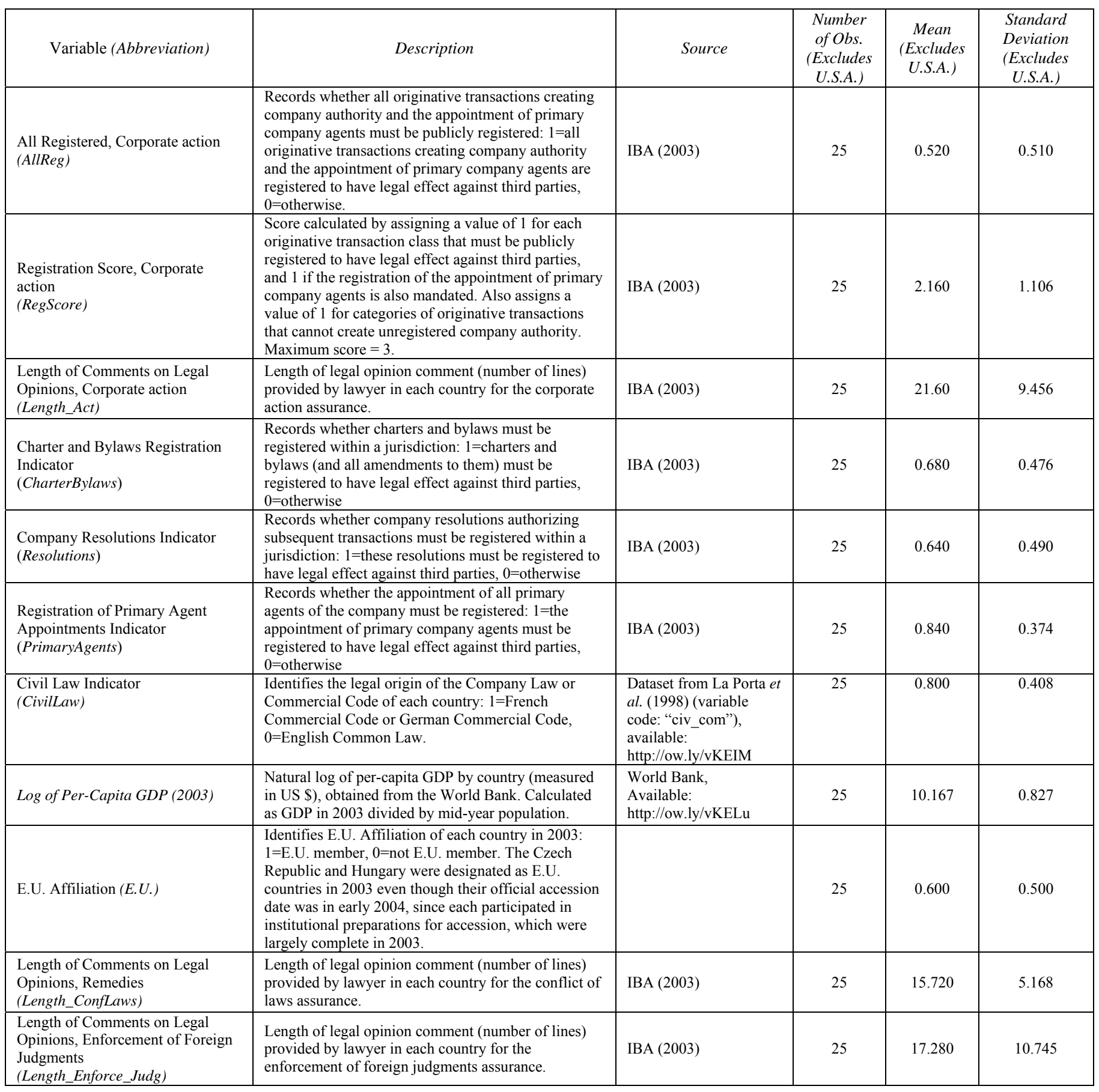




\section{THE TRADEOFF BETWEEN EX ANTE AND EX POST TRANSACTION COSTS}

TABLE 2. Relationship Between Registration of Originative Transactions and the Length of Corporate Action Assurance Comments. Dependent Variable: Legal Opinion Comment Length, Corporate Action Assurance (Length_Act).

\begin{tabular}{|c|c|c|c|c|}
\hline $\begin{array}{l}\text { Independent } \\
\text { Variables }\end{array}$ & Equation 1 & Equation 2 & Equation 3 & Equation 4 \\
\hline Intercept & $\begin{array}{c}25.42 * * * \\
(2.561)\end{array}$ & $\begin{array}{c}27.44 * * * \\
(4.087)\end{array}$ & $\begin{array}{c}7.099 \\
(28.23)\end{array}$ & $\begin{array}{c}16.83 \\
(29.85)\end{array}$ \\
\hline AllReg & $\begin{array}{l}-7.340^{*} \\
(3.551)\end{array}$ & & $\begin{array}{l}-7.709 * \\
(4.068)\end{array}$ & \\
\hline RegScore & & $\begin{array}{l}-2.704 \\
(1.691)\end{array}$ & & $\begin{array}{l}-4.944^{*} \\
(2.643)\end{array}$ \\
\hline CivilLaw & & & $\begin{array}{c}2.576 \\
(5.043)\end{array}$ & $\begin{array}{c}9.195 \\
(6.878)\end{array}$ \\
\hline E.U. & & & $\begin{array}{l}-0.104 \\
(4.754)\end{array}$ & $\begin{array}{l}-0.763 \\
(4.698)\end{array}$ \\
\hline $\begin{array}{l}\text { Log of GDP Per } \\
\text { Capita }\end{array}$ & & & $\begin{array}{c}1.624 \\
(2.801)\end{array}$ & $\begin{array}{c}0.841 \\
(2.919)\end{array}$ \\
\hline $\mathrm{N}$ & 25 & 25 & 25 & 25 \\
\hline R-Squared & 0.157 & 0.100 & 0.186 & 0.183 \\
\hline
\end{tabular}

Standard errors in parentheses. ${ }^{*} \mathrm{p}<0.10,{ }^{* *} \mathrm{p}<0.05, * * * \mathrm{p}<0.01$. 


\section{THE TRADEOFF BETWEEN EX ANTE AND EX POST TRANSACTION COSTS}

TABLE 3. Relationship Between Registration of Originative Transaction Indicators and the Length of Corporate Action Assurance Comments. Dependent Variable: Legal Opinion Comment Length, Corporate Action Assurance (Length_Act).

\begin{tabular}{|c|c|c|c|c|c|c|}
\hline $\begin{array}{l}\text { Independent } \\
\text { Variables }\end{array}$ & Equation 5 & Equation 6 & Equation 7 & Equation 8 & Equation 9 & Equation 10 \\
\hline Intercept & $\begin{array}{l}29.12 * * * \\
(2.836)\end{array}$ & $\begin{array}{l}22.78 * * * \\
(3.205)\end{array}$ & $\begin{array}{c}23.75 * * * \\
(4.805)\end{array}$ & $\begin{array}{c}23.91 \\
(25.03)\end{array}$ & $\begin{array}{l}-2.801 \\
(30.33)\end{array}$ & $\begin{array}{c}1.303 \\
(33.92)\end{array}$ \\
\hline CharterBylaws & $\begin{array}{c}-11.07 * * * \\
(3.439)\end{array}$ & & & $\begin{array}{c}-14.59 * * * \\
(4.209)\end{array}$ & & \\
\hline Resolutions & & $\begin{array}{l}-1.840 \\
(4.006)\end{array}$ & & & $\begin{array}{l}-1.400 \\
(4.797)\end{array}$ & \\
\hline PrimaryAgents & & & $\begin{array}{l}-2.560 \\
(5.243)\end{array}$ & & & $\begin{array}{l}-4.390 \\
(12.62)\end{array}$ \\
\hline CivilLaw & & & & $\begin{array}{c}7.836 \\
(4.738)\end{array}$ & $\begin{array}{c}0.871 \\
(5.855)\end{array}$ & $\begin{array}{c}3.556 \\
(11.16)\end{array}$ \\
\hline E.U. & & & & $\begin{array}{c}0.730 \\
(4.061)\end{array}$ & $\begin{array}{l}-2.048 \\
(5.028)\end{array}$ & $\begin{array}{l}-2.004 \\
(5.028)\end{array}$ \\
\hline $\begin{array}{l}\text { Log of GDP Per } \\
\text { Capita }\end{array}$ & & & & $\begin{array}{l}0.0895 \\
(2.471)\end{array}$ & $\begin{array}{c}2.540 \\
(3.006)\end{array}$ & $\begin{array}{c}2.197 \\
(3.259)\end{array}$ \\
\hline $\mathrm{N}$ & 25 & 25 & 25 & 25 & 25 & 25 \\
\hline R-Squared & 0.310 & 0.00909 & 0.0103 & 0.400 & 0.0436 & 0.0453 \\
\hline
\end{tabular}

Standard errors in parentheses. ${ }^{*} \mathrm{p}<0.10,{ }^{* *} \mathrm{p}<0.05,{ }^{* * *} \mathrm{p}<0.01$. 


\section{THE TRADEOFF BETWEEN EX ANTE AND EX POST TRANSACTION COSTS}

TABLE 4. Robustness Exercises. Dependent Variable: Legal Opinion Comment Length, Corporate Action Assurance (Length_Act).

\begin{tabular}{|c|c|c|c|c|c|c|}
\hline & Equation 11 & Equation 12 & Equation 13 & Equation 14 & Equation 15 & Equation 16 \\
\hline Intercept & $\begin{array}{c}36.47 \\
(26.01)\end{array}$ & $\begin{array}{c}16.29 \\
(31.37)\end{array}$ & $\begin{array}{c}34.42 \\
(32.15)\end{array}$ & $\begin{array}{l}78.30^{*} \\
(37.33)\end{array}$ & $\begin{array}{c}69.08 \\
(58.83)\end{array}$ & $\begin{array}{c}80.30 \\
(49.97)\end{array}$ \\
\hline CharterBylaws & $\begin{array}{c}-17.32 * * * \\
(4.476)\end{array}$ & & & $\begin{array}{c}-19.16^{* * *} \\
(4.773)\end{array}$ & & \\
\hline AllReg & & $\begin{array}{l}-9.151 * \\
(4.601)\end{array}$ & & & $\begin{array}{l}-9.014 \\
(5.887)\end{array}$ & \\
\hline RegScore & & & $\begin{array}{c}-8.342 * * \\
(3.624)\end{array}$ & & & $\begin{array}{l}-7.994 * \\
(3.690)\end{array}$ \\
\hline CivilLaw & & & & $\begin{array}{l}19.71 * * \\
(6.287)\end{array}$ & $\begin{array}{c}9.932 \\
(8.128)\end{array}$ & $\begin{array}{l}24.36^{*} \\
(11.70)\end{array}$ \\
\hline E.U. & $\begin{array}{c}5.163 \\
(4.545)\end{array}$ & $\begin{array}{c}4.108 \\
(5.701)\end{array}$ & $\begin{array}{c}3.434 \\
(5.427)\end{array}$ & & & \\
\hline $\begin{array}{c}\text { Log of GDP Per } \\
\text { Capita }\end{array}$ & $\begin{array}{l}-0.446 \\
(2.641)\end{array}$ & $\begin{array}{c}0.787 \\
(3.254)\end{array}$ & $\begin{array}{c}0.599 \\
(3.154)\end{array}$ & $\begin{array}{l}-5.677 \\
(3.463)\end{array}$ & $\begin{array}{l}-4.817 \\
(5.464)\end{array}$ & $\begin{array}{l}-5.864 \\
(4.637)\end{array}$ \\
\hline $\mathrm{N}$ & 20 & 20 & 20 & 15 & 15 & 15 \\
\hline R-Squared & 0.494 & 0.215 & 0.264 & 0.686 & 0.361 & 0.457 \\
\hline
\end{tabular}

Standard errors in parentheses. ${ }^{*} \mathrm{p}<0.10,{ }^{* *} \mathrm{p}<0.05,{ }^{* * *} \mathrm{p}<0.01$. 


\section{THE TRADEOFF BETWEEN EX ANTE AND EX POST TRANSACTION COSTS}

TABLE 5. Placebo Tests.

\begin{tabular}{|c|c|c|c|c|c|c|}
\hline & Equation 17 & Equation 18 & Equation 19 & Equation 20 & Equation 21 & Equation 22 \\
\hline $\begin{array}{l}\text { Independent } \\
\text { Variables }\end{array}$ & \multicolumn{3}{|c|}{ Dependent Variable: Length_ConfLaws } & \multicolumn{3}{|c|}{ Dependent Variable: Length_Enforce_Judg } \\
\hline Intercept & $\begin{array}{c}14.58 * * * \\
(1.488)\end{array}$ & $\begin{array}{c}15.05^{* * *} * \\
(2.349)\end{array}$ & $\begin{array}{c}15.75 * * * \\
(2.733)\end{array}$ & $\begin{array}{c}17.42^{* * *} \\
(3.168)\end{array}$ & $\begin{array}{c}19.42 * * * \\
(4.870)\end{array}$ & $\begin{array}{c}20.50 * * * \\
(1.528)\end{array}$ \\
\hline AllReg & $\begin{array}{c}2.186 \\
(2.064)\end{array}$ & & & $\begin{array}{l}-0.263 \\
(4.394)\end{array}$ & & \\
\hline RegScore & & $\begin{array}{c}0.311 \\
(0.972)\end{array}$ & & & $\begin{array}{l}-0.992 \\
(2.015)\end{array}$ & \\
\hline CharterBylaws & & & $\begin{array}{c}0.857 \\
(3.038)\end{array}$ & & & $\begin{array}{l}-4.185 \\
(11.23)\end{array}$ \\
\hline Resolutions & & & $\begin{array}{c}1.714 \\
(2.801)\end{array}$ & & & $\begin{array}{c}4.602 \\
(4.645)\end{array}$ \\
\hline PrimaryAgents & & & $\begin{array}{l}-2.036 \\
(4.399)\end{array}$ & & & $\begin{array}{l}-3.952 \\
(9.389)\end{array}$ \\
\hline $\mathrm{N}$ & 25 & 25 & 25 & 25 & 25 & 25 \\
\hline R-Squared & 0.0465 & 0.00442 & 0.0214 & 0.000156 & 0.0104 & 0.0667 \\
\hline
\end{tabular}

Standard errors in parentheses. ${ }^{*} \mathrm{p}<0.10,{ }^{* *} \mathrm{p}<0.05,{ }^{* * *} \mathrm{p}<0.01$. 
ANNEX 1. Building the Index for One Jurisdiction.

The IBA (2003) provides the following legal opinion comment pertaining to the corporate action assurance in Hungary:

The Articles of Association sometimes include limitations for certain transactions (especially transactions in excess of a certain value) subjecting them to the prior approval of the board of directors or the shareholders' meeting. In such cases, a legal opinion that "all corporate actions have been taken" or that the company was "authorized" to enter into a particular agreement can be rendered only upon receipt of evidence of the approval by the company's appropriate company body. Such company resolution is not necessarily filed with the Court of Registration; therefore the cooperation of the company is required in order to furnish counsel with the necessary verification.

The Company Act authorizes the managing director of a limited liability company and the members of the board of directors of a company limited by shares [internal page reference] to represent and act on behalf of the company. In addition, the shareholders' meeting or the officers of the company may authorize certain employees of the company to legally bind the company with regard to certain matters. The Company Act includes restrictions regarding limitations on the representative power of such officers or employees. Further, the Company Act requires the registration of the name of each officer and employee who is entitled to act on behalf of the company with the Court of Registration together with the specimen signature of each such representative (taken and issued by a notary public verifying its authenticity). All above-mentioned information, including the specimen signature, is available to the public at the Court of Registration.

Consequently, we coded the length of Hungary's comment for the corporate action assurance (the dependent variable, Length_Act) as 22 lines (the number of lines within the IBA (2003) text). We also coded the independent variables as follows: Given that, in Hungary, the Articles of Association (containing most elements of charters and bylaws in the United States) as well as the identity of all agents authorized to transact on behalf of a company must be registered, but some company resolutions providing for special authorizations of specific transactions need not be registered, we gave Hungary an AllReg score of zero. The RegScore variable received a value of two, representing the registration of the charter and bylaws (contributing one point to the score), as well as the identity of primary company agents (contributing one more point). Further, the CharterBylaws indicator received a value of one, the Resolutions indicator a value of zero, and the PrimaryAgents indicator a value of one. Moreover, we coded the control variables as follows: the CivilLaw indicator received a value of one, reflecting the civil law origin of Hungary's commercial code, and the E.U. indicator a value of one, reflecting Hungary's E.U. affiliation. Lastly, Hungary's per-capita GDP in 2003 (in 2012 U.S. \$) was $\$ 10,085$, and for the regressions we used the natural log of per-capita GDP. 


\section{THE TRADEOFF BETWEEN EX ANTE AND EX POST TRANSACTION COSTS}

\section{ANNEX 2. Entities and Governing Documents Studied.}

\begin{tabular}{|c|c|c|c|}
\hline Country & Entity & Charter & Bylaws \\
\hline Argentina & Sociedad Anónima (SA) & Acto Constitutivo & Estatutos \\
\hline Australia & $\begin{array}{l}\text { Public Company (limited } \\
\text { liability company) }\end{array}$ & Constitution & Constitution \\
\hline Austria & $\begin{array}{l}\text { Aktiengesellschaft (AG); } \\
\text { Gesellschaft mit beschränkter } \\
\text { Haftung }(\mathrm{GmbH})\end{array}$ & Satzung (AG); Gesellschaftsvertrag (GmbH) & Satzung (AG); Gesellschaftsvertrag $(\mathrm{GmbH})$ \\
\hline Belgium & $\begin{array}{l}\text { Société Anonyme; Naamloze } \\
\text { Vennootschap (NV) }\end{array}$ & Acte constitutif/oprichtingsakte; Statuts/statute & Acte constitutif/oprichtingsakte; Statuts/statute \\
\hline Brazil & $\begin{array}{l}\text { Sociedade Anônima (S/A); } \\
\text { Sociedade por Quotas de } \\
\text { Responsabilidade Limitada } \\
\text { (LTDA) }\end{array}$ & $\begin{array}{l}\text { Ata da Assembléia Geral de Constituição and } \\
\text { Estatuto (S/A); Contrato Social (LTDA) }\end{array}$ & $\begin{array}{l}\text { Ata da Assembléia Geral de Constituição and } \\
\text { Estatuto (S/A); Contrato Social (LTDA) }\end{array}$ \\
\hline $\begin{array}{l}\text { Canada } \\
\text { (Ontario) }\end{array}$ & Corporation & Articles of Incorporation & Bylaws \\
\hline Colombia & Sociedad Anónima (SA) & Escritura de Constitución & Escritura de Constitución \\
\hline Czech Republic & $\begin{array}{l}\text { Akciová Společnost (a.s.); } \\
\text { Společnosti s Ručením } \\
\text { Omezeným (s.r.o.) }\end{array}$ & $\begin{array}{l}\text { Zakladatel'ská Listina (one-shareholder a.s., one- } \\
\text { shareholder s.r.o.); Zakladatel'ská Smlouva (more } \\
\text { than one-shareholder a.s.); Společenská Smlouva } \\
\text { (s.r.o. with more than one-shareholder); Stanovy } \\
\text { (a.s., optionally for s.r.o.) }\end{array}$ & $\begin{array}{l}\text { Zakladatel'ská Listina (one-shareholder a.s., one- } \\
\text { shareholder s.r.o.); Zakladatel'ská Smlouva } \\
\text { (more than one-shareholder a.s.); Společenská } \\
\text { Smlouva (s.r.o. with more than one- } \\
\text { shareholder); Stanovy (a.s., optionally for s.r.o.) }\end{array}$ \\
\hline Denmark & $\begin{array}{l}\text { Aktieselskaber; } \\
\text { Anpartselskaber }\end{array}$ & Stiftelsesoverenskomster and Vedtaegter & Stiftelsesoverenskomster and Vedtaegter \\
\hline England & $\begin{array}{l}\text { Public Company; Private } \\
\text { Company }\end{array}$ & Memorandum of Association & Articles of Association \\
\hline Finland & Osakeyhtiö; Aktiebolag & Perustamiskirja & Yhtiöjärjestys \\
\hline France & $\begin{array}{l}\text { Société Anonyme; Société à } \\
\text { Responsabilité Limitée (SARL) }\end{array}$ & Statuts & Statuts \\
\hline Germany & $\begin{array}{l}\text { Aktiengesellschaft (AG); } \\
\text { Gesellschaft mit beschränkter } \\
\text { Haftung }(\mathrm{GmbH})\end{array}$ & Satzung (AG); Gesellschaftsvertrag $(\mathrm{GmbH})$ & Satzung (AG); Gesellschaftsvertrag $(\mathrm{GmbH})$ \\
\hline Greece & $\begin{array}{l}\text { Anonymi Etairia (A.E.); Etairia } \\
\text { Periorismenis Efthinis (EPE) }\end{array}$ & Katastatiko ("Statute") & Katastatiko ("Statute") \\
\hline Hungary & $\begin{array}{l}\text { Részvénytársaság ("rt", } \\
\text { company limited by shares, } \\
\text { similar to German AG); } \\
\text { Korlátolt Felelösségü Társaság } \\
\text { ("kft", limited liability } \\
\text { company, similar to German } \\
\text { GmbH); }\end{array}$ & $\begin{array}{l}\text { Alapszabály (rt), Társasági Szerzödés (kft), } \\
\text { Alapító Okirat (one-member kft) }\end{array}$ & $\begin{array}{l}\text { Alapszabály (rt), Társasági Szerződés (kft), } \\
\text { Alapító Okirat (one-member kft) }\end{array}$ \\
\hline Ireland & $\begin{array}{l}\text { Public Company; Private } \\
\text { Company }\end{array}$ & Memorandum of Association & Articles of Association \\
\hline Italy & $\begin{array}{l}\text { Primarily, Società per Azioni } \\
\text { (SpA), but also can be applied } \\
\text { to: Società Inaccomandita per } \\
\text { Azioni and Società a } \\
\text { Responsibilità Limitata (Srl) } \\
\end{array}$ & Atto Constitutivo & Statuto \\
\hline Japan & Kabushiki Kaisha & Teikan & Teikan \\
\hline Korea & Chusik Hoesa & Jung-gwan & Jung-gwan \\
\hline Luxembourg & $\begin{array}{l}\text { Société Anonyme; Société à } \\
\text { Responsabilité Limitée }\end{array}$ & Statuts & Statuts \\
\hline The Netherlands & $\begin{array}{l}\text { Naamloze Vennootschap (NV, } \\
\text { public limited company); } \\
\text { Besloten Vennootschap (BV, } \\
\text { private limited company) }\end{array}$ & Akte Van Oprichting (Deed of Incorporation) & Statuten (Articles of Association) \\
\hline South Africa & $\begin{array}{l}\text { Proprietary Limited ("Pty Ltd", } \\
\text { private limited liability } \\
\text { company); Limited ("Ltd", } \\
\text { public limited liability } \\
\text { company) }\end{array}$ & Memorandum of Association & Articles of Association \\
\hline Spain & Sociedad Anónima (SA) & Escritura de Constitución; Estatutos Sociales & Escritura de Constitución; Estatutos Sociales \\
\hline Switzerland & Aktiengesellschaft (AG) & Statuten & Statuten \\
\hline United States & Corporation & Charter & Bylaws \\
\hline Venezuela & $\begin{array}{l}\text { Compañía Anónima; Sociedad } \\
\text { Anónima }\end{array}$ & Acta Constitutiva & Estatutos \\
\hline
\end{tabular}

